while Fayrer's large, open forehead and calm expression reminded me of an elephant, and one could hardly look at him without thinking how rightly the Hindoos have chosen an elephant's head for their god of wisdom. Both men were alike in the stern uprightness of their characters, in the extent of their knowledge and the wideness of their interests, in the clearness of their views, the correctness of their decisions, their absolute fearlessness, their promps and energetic action, their firm determination to carry out what they thought right, in their tenacity of purpose, in a certain impatience of opposition, and in their great success in overcoming it. Associated with these qualitics which compelled admiration were an extraordinary kindness and tenderness of heart which gained the affection of all who knew them.

It is not so easy to draw a comparison between their intellectual powers, because their spheres of activity were so very different. Huxley's life was passed in the pursuit and teaching of science and philosophy; Fayrer's scientific work was done in the short intervals of time that he could snatch from the pressure of other occupations. While Huxley was on board the Rattlesnake, Fayrer was engaged in amputating limbs and treating gunshot wounds in the insurrection at Palermo, and narrowly escaped death at the siege of Rome by the French. Between such occupations, however, he managed to learn sufficient Italian to pass the examinations and obtain the degree of M.D. in the University of Romre, perhaps the only doctor not a Roman Catholic who ever did so.

Before his friend Huxley had come back from his voyage, Fayrer went out to India, and again saw active service in the Burmese war. During this war he distinguished himself so highiy that the GovernorGeneral appointed him residency surgeon at Lucknow, the best appointment at his disposal, as a reward for his services.

In order to carry on his work he had to learn Hindostani and Persian, and in addition to all his medical work he had to conduct a great deal of the correspondence between the British Government and the King of Oude. When the Indian Mutiny broke out, Favrer's house in Lucknow was one of the most exposed to the enemy's attack, and he himself took an active part in the defence of the town as well as attending to all the medical and surgical work which disease from insanitary conditions, unsuitable food and the wounds by shot and shell caused amongst the besieged.

Broken in health, Fayrer returned to England after the Mutiny, but instead of remaining idle he went to Edinburgh, worked at the university, passed his examinations, and received the degree of M.D. He then returned to India, where he became professor of surgery in Calcutta.

In 1870 he went with the Duke of Edinburgh on his travels in India, and in 1875 accompanied the King, who was then Prince of Wales, to India. $\mathrm{He}$ was a keen sportsman, and was fond of zoology, and in 1867 , when president of the Asiatic Society of Bengal, he proposed to found a Zoological Gardens in Calcutta, a proposition which, after some years, was carried into effect. $\mathrm{He}$ also proposed an ethnological investigation of the races of India, but this was never fully carried out.

Much of his time was taken up by pathological investigation and sanitary work, but the research in which he took the greatest interest was his zoological work on the snakes of India and his physiological investigation into the action of their venom. It was during this investigation that he first tried the effect of various antidotes, one of which; permanganate of potash, is now beginning to be used in such a way as to preserve life in cases of snake bite which would otherwise have been fatal. The difficulties under which his scientific work was carried out are shown by the fact that he had often to leave an experiment of this kind in order to attend to his hospital work, and that while there amputating a limb or performing some other operaticn his mind would be disturbed by anxiety regarding the condition of his private patients, who were anxiously waiting for him. But for Fayrer's extensive knowledge and firm dedecision in difficult circumstances, the Prince of Wales, with whom he was travelling, might possibly have been induced by the earnest entreaties of various personages to visit infected places, with the probable result that cholera might have spread over large districts of India, and that our King might never have returned from his visit to that part of his. Empire. Not only do scientific men owe a great debt to Fayrer for his own contributions to science and for the bias he gave to Huxley's life, but also for the care which he took of our King's life and the benefits which its preservation has conferred upon the Empire.

At Fayrer's funeral one of the wreaths bore the gracious inscription,

"For Auld Lang Syne from Edward VII.'

LAUDER BRUNTON.

\section{SIR DIETRICH BRANDIS, K.C.I.E., F.R.S.}

$\mathrm{B} Y$ the death of Sir Dietrich Brafdis, which oc$B$ curred at Bonn on May 8 , of world-wide

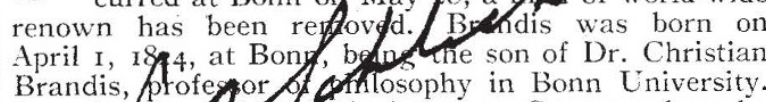
As a boy he flow his father to Greece, where he spent sulears. On his return to Germany he was educated at the Universities of Copenhagen, Göttingen, and Bonn. He became, in 1849 , lecturer (Privat-docent) on botany at Bonn. In ${ }^{1} 8_{54}$ he married a daughter of Dr. Marshman, of Bengal. This happened to be the turning-point in his career.

After the occupation of the province of Pegu in Burma, Lord Dalhousie was looking for a man to take charge of the important teak forests of that province, when his attention was directed to Brandis by the latter's brother-in-law, General Sir Henry Havelock. Lord Dalhousie wrote to Brandis that if he would come to India he would be appointed superintendent of the Pegu teak forests. The offer was accepted, and Brandis landed at Calcutta in 18,56 . He explained his views to Lord Dalhousie, who, in taking leave of him, said, "Dr. Brandis, if you carry out the scheme which you have explained to me, you will confer a great benefit upon this country." Brandis never saw Lord Dalhousie again, but his parting words remained with him throughout his service. Brandis set to work to save the Burma teak forests, in which endeavour he had the full support of Major (afterwards Sir Arthur) Phayre. After a longcontinued struggle the forests were placed under systematic management, and they, with the forests of Upper Burma, are now the chief supply of teak timber to the world.

In 1862 , Brandis was called to Simla, at the suggestion, it is believed, of Dr. Cleghorn, one of the principal pioneers of forest conservancy in India, to advise the Government of India on forest matters in other provinces, and in $\mathrm{I}_{86}$ he was appointed the first Inspector-General of Forests to the Government of India. He then set to work to introduce systematic forest management throughout India. A regular department was established and a forest law passed. Brandis travelled from one end of the Bengal. Presidency to the other, advising and organising the department. $\mathrm{He}$ also visited Bombay twice, and No. I962, rol. 76] 
spent two years $(188 \mathrm{r}-3)$ in Madras. The department thus created has grown until it has now an area of 239,000 square miles, equal to twice the area of Great Britain and Ireland, under its management.

When Brandis first started operations he had to do with what staff he could lay his hands on; but he determined to obtain one fit to deal with the requirements of the case. In I866, while on sick leave in England, he obtained the sanction of the late Lord Salisbury, then Secretary of State for India, to train young Englishmen in Continental forest schools, and under this scheme a number of highly qualified foresters have been sent to India. The training at Continental forest schools was subsequently supplanted by that at Coopers Hill College, and now at the University of Oxford.

But Brandis went a step further. In 1878 he started a forest school at Dehra Dun for the training of natives of India, which has now been raised to the rank of "The Imperial Indian Forest College," and sends annually from forty to fifty trained executive officers into the service.

By these means a trained staff of 200 Englishmen have been obtained, who control the operations of the forest department, assisted by about ir,00o native officials of various grades. The results are most gratifying. The supply of timber, firewood, grass, and other produce for the teeming millions of India has been placed on a satisfactory footing, while the net revenue from the forests has risen from 40 ,oool. in 1864 to $668 ; 000 l$. in 1904, although produce valued at a similar sum is giver free to the people of the country.

During his career in India Brandis' wrote an endless number of reports, and in $1874^{\circ}$ he brought out the "Forest Flora of North-west and Central India," a work which was so highly thought of by Sir Joseph Hooker and others that he was made a Fellow of the Royal Society in 1875 . It may not be generally known that Brandis was the first who compiled a rainfall map of India; it has been improved since, but as regards the main points it holds good to this day.

Brandis retired from the Indian service in $188_{3}$, at the age of fifty-nine years; but he continued to devote himself to the advancement of forest conservancy in India, by articles and letters of advice to his friends in India. From 1888 to 1896 he superintended the practical instruction in Germany of the Coopers Hill forest students.

The last eight years of his life he devoted to the writing of a general Indian forest flora, which he published in I 906 under the title of "Indian Trees," a monumental work, which is likely to be the standing book of reference on the subject for another generation. Scarcely had he completed this when he fell ill, and he never rose from his sick bed. He was made a C.I.E. in 1876 , and a K.C.I.E. in 1887 .

It should not be omitted to mention that Brandis had a great share in the development of forest conservancy in the United States. He guided the studies of quite a number of young Americans, who have since established a great department in the United States. His influence in this respect has been so great that President Roosevelt presented him with his picture and the following dedication :- "To Sir Dietrich Brandis in high appreciation of his services to forestry in the United States, from Theodore Roosevelt.'

Apart from India and the United States, Brandis's action has been felt in almost all parts of the British Empire, including these islands. $\mathrm{He}$ has left his mark upon every continent of the earth; at any rate, his name will go to posterity as the father of systematic forest management in the British Empire.

NO. I962, VOL. 76$]$

W. Schlich.

\section{NOTES.}

We regret to learn that Dr. Maxwell T. Masters, F.R.S., whose ffitings on botanical and horticultural subjects are fanhliar to many readers of Nature, died on May 30 at sereny-four years of age.

Tulz annual conyrsazione of the Institution of Electrical Engineers will held at the Natural History Museum, Cromwell Road on Tuesday evening, June 18.

DR. W. S. Brfuce and the remainder of his staff, who are starting on an expedition to the Arctic, have left Edinburgh for Spifbergen. The expedition will finally be relieved and bre ught back to Europe by the Prince of Monaco on board his yacht the Princess Alice.

Prof. Paul Elrrich will deliver the second and third of his series of Harben fectuffof the Royal Institute of Public Healty on Friday J 7 , and Tuesday, June 11 . The subject of the ettures is "Experimental Researches on Specific fruer peutics," and they will be delivered at the Royal Medich-Chirurgical Society, 20 Hanover Square, at 5 p.m. on each day.

Gilbert White's autograph manuscript of his " Natural History and Antiquities of Selborne," in the form of letters to Thomas Pennant agd Daines Barrington, and arranged in a folio volume, yill be sold by Messrs. Sotheby on July I. The MS. remained in the possession of the author's descendans until 1895 , when it was sold at Sotheby's and acquired by the present owner, Mr. Stuart M. Samuel, M.P

THE counet of the Society of Arts, with the approval of His Royal Highness the Prince of Wales, its president, has zwarded the Albert medal of the society for the current ar to the Earl of Cromer "In recognition of his preeminent public services in Egypt, where he has imparted security to the relations of this country with the East, has established justice, restored order and prosperity, and, by the initiation of great works, has opened up new fields for enterprise."

AT a meeting of the Corporation of the City of London on May 30, the Lord Mayor presiding, it was decided unanimously to present the freedom of the City to Lord Lister and the Earl of Cromer. Mr. Alderman Alliston, in moving that the hopgrary freedom of the City be presented to Lord Lister in a/gold box, in recognition of his eminence as a surgeon and the invaluable services he has rendered to humanity by the discovery of the antiseptic system, remarked that more than one hundred years have elapsed since the Court bestowed the freedom of the City on a member of the medical or surgical profession. The last was that given to Edward Jenner, the discoverer of vaccination, in $\mathrm{I}^{8} \mathrm{o}_{3}$. Since then the Corporation has welcomed Royal personages, great warriors, eminent statesmen, and others, but the still small voice of the personal ills that flesh is heir to-their amelioration and remedy-have, $\mathrm{Mr}$. Alliston pointed out, somewhat escaped the City's notice. The deficiency is now to be rectified, and the City Lands Committee has been empowered to make the necessary arrangements for the presentation of the freedom to Lord Lister at an early date.

ON August 15, weather permitting, the international laboratory for Alpine investigations, at the Col d'Olen, on Monte Rosa, will be formally opened. In tivo articles contributed by the Sir Michael Foster to NATURE (vol. lxv., p. 568, and 1axi., p. 443), he described the laboratory established the Gnifetti peak of Monte Rosa, at 